\title{
Response of Organic and Inorganic Nutrient Sources on the Growth and Flowering of Gladiolus primulinus cv. Candyman
}

\author{
Nini R. Kuotsu*, Rokolhuii Keditsu and Laishram Hemanta \\ Department of Horticulture, School of Agricultural Sciences and Rural Development, \\ Nagaland University, Medziphema-797106, Nagaland, India \\ *Corresponding author
}

A B S T R A C T

\begin{abstract}
Keywords
Gladiolus, Organic, Inorganic nutrient sources, Growth, Flowering

\section{Article Info}

Accepted:

18 April 2018

Available Online:

10 May 2018 Medziphema Campus during 2014-15 and 2015-16 to study the response of various sources of nutrients in gladiolus production. The experiment was laid out in RBD with 14 treatments and 3 replications. The treatments were $T_{0}$ (Control), $T_{1}\left(F Y M 40 \mathrm{tha}^{-1}\right), \mathrm{T}_{2}$ (Pig manure $35 \mathrm{t} \mathrm{ha}^{-1}$ ), $\mathrm{T}_{3}$ (Vermicompost $10 \mathrm{t} \mathrm{ha}^{-1}$ ), $\mathrm{T}_{4}$ (NPK 100\% RDF i.e. 200:200:200 kg NPK ha $\left.{ }^{-1}\right) ; \mathrm{T}_{5}$ (Azospirillum + Phosphotica), $\mathrm{T}_{6}(50 \% \mathrm{NPK}+50 \% \mathrm{FYM}), \mathrm{T}_{7}(50 \%$ $\mathrm{NPK}+50 \%$ Pig manure), $\mathrm{T}_{8}(50 \% \mathrm{NPK}+50 \%$ Vermicompost $), \mathrm{T}_{9}(50 \% \mathrm{NPK}+$ Azospirillum + Phosphotica), $\mathrm{T}_{10}$ (75\% NPK + Azospirillum + Phosphotica), $\mathrm{T}_{11}$ (50\% $\mathrm{NPK}+25 \% \mathrm{FYM}+$ Azospirillum + Phosphotica), $\mathrm{T}_{12}(50 \% \mathrm{NPK}+25 \%$ Pig manure + Azospirillum + Phosphotica) and $\mathrm{T}_{13}(50 \% \mathrm{NPK}+25 \%$ Vermicompost + Azospirillum + Phosphotica). Pooled data revealed that $T_{11}$ exhibited better result with respect to plant height $(108.55 \mathrm{~cm})$ and leaves plant ${ }^{-1}(9.63) . \mathrm{T}_{12}$ recorded higher leaf area $\left(130.56 \mathrm{~cm}^{2}\right)$, minimum days to spike emergence (68.72) and opening of first floret (78.36), maximum length of spike $(88.76 \mathrm{~cm})$ and rachis $(48.84 \mathrm{~cm})$, more diameter of floret $(10.33 \mathrm{~cm})$ and florets spike ${ }^{-1}$ (15.58), longer durability of spikes (19.42 days) and spikes plant ${ }^{-1}(1.48)$.
\end{abstract}

Present experiment was carried out in the Experimental Farm, Department of Horticulture, School of Agricultural Sciences and Rural Development, Nagaland University,

\section{Introduction}

Gladiolus (Gladiolus sp.) is an all-time favorite for the cut-flower industry as it occupies a leading position among cut flowers due to its elegant appearance and spikes of different hues and having long vase life (Anderson et al., 2012; Sajjad et al., 2014). However, flower crops especially bulbous plants are very much responsive to fertilizer and are highly capable of exhausting huge nutrients from native soil thus require higher amount of fertilizer in balance proportion for ensuring maximum flower production. At present, there is an urgent need to standardize agro techniques which are most suitable for local climatic and edaphic conditions. However, information regarding organic and inorganic nutrient sources as well as their integrated use in gladiolus cultivation especially in Nagaland condition is extremely lacking. Thus, there is immense need to 
generate sufficient information on various parameters. Keeping in view the above facts, an investigation was carried out to evaluate the response of organic and inorganic nutrient sources on the growth and flowering of Gladiolus primulinus cv. Candyman.

\section{Materials and Methods}

A field experiment was carried out to evaluate the response of organic and inorganic nutrient sources on the growth and flowering of Gladiolus primulinus cv. Candyman in the Experimental farm of Horticulture, Nagaland University, School of Agricultural Sciences and Rural Development, Medziphema Campus, Nagaland during 2014-2016. The soil type of the experimental site was sandy loam having a $\mathrm{pH}$ of 4.75 , organic carbon $1.74 \%$, available $\mathrm{N}, \mathrm{P}$ and $\mathrm{K}$ of $240.8,17.12$ and $219.4 \mathrm{~kg} \mathrm{ha}^{-1}$ respectively. The experiment consisted of fourteen treatments replicated three times in a randomized block design (Table 1). The $100 \%$ recommended dose of fertilizer for gladiolus was 200:200:200 kg ha $^{-1}$ available $\mathrm{N}, \mathrm{P}$ and $\mathrm{K}$, respectively. The sources of $\mathrm{N}, \mathrm{P}_{2} \mathrm{O}_{5}$ and $\mathrm{K}_{2} \mathrm{O}$ as urea, SSP and MoP were applied, respectively. The entire amounts of SSP and MoP were applied during September at the time of final bed preparation. For the treatment combinations which consisted of organic nutrient sources, the required amount were worked out with respect to available $\mathrm{N}$ content of organic nutrient sources. The nutrient profiling for the various organic nutrient sources under study are presented in Table 2. Manures were applied by incorporating into the soil two weeks prior to planting. Nitrogen was applied in three equal installments at 15, 30 and 45 days after sowing. Biofertilizers were inoculated to the corms before planting by corm dip method for 30 minutes and shade dried prior to planting. Standard package of practices were followed to grow gladiolus crop. Five plants were randomly selected from each plot and were tagged for the collection of field data for vegetative, floral and yield attributes. The data collected from the experiment were subjected to analysis of variance technique (ANOVA) for Randomized Block Design (Panse and Sukhatme, 1989) and the treatment variance was tested against error variance by applying Fischer Snedecor ' $F$ ' tests of probability at 5 percent level.

\section{Results and Discussion}

\section{Growth characters}

The data pertaining to growth characters viz. sprouting of corms, plant height, leaves plant ${ }^{-1}$ and leaf area as influenced by different treatments has been presented in Table 3. The variations in sprouting of corms during both the seasons of experimentation under different treatments were quite marginal and could not reach the level of significance. This may be because in bulbous crops the variation in time to sprouting is known to depend on food materials stored within the bulb. The corms of gladiolus store food from the previous season's growth which is used to sustain the plant for its initial growth and development. The present result is in conformity with the reports of Gagbhiye (2013) and Sharma et al., (2003) who reported that sprouting of corms in gladiolus depends upon the stored food materials in the corm and not the external nutrition.

The data on plant height were recorded at spike initiation stage and the perusal of the data revealed that the treatment $\mathrm{T}_{11}(50 \% \mathrm{NPK}$ $+25 \%$ FYM + Biofertilizers) emerged as the tallest plant $(108.55 \mathrm{~cm})$ which was at par with $\mathrm{T}_{7}$ (50\% NPK $+50 \%$ Pig manure) $(107.80 \mathrm{~cm})$ and $\mathrm{T}_{12}(50 \% \mathrm{NPK}+25 \%$ Pig manure + Biofertilizers $)(107.63 \mathrm{~cm})$ while control recorded the least effective treatment $(80.88 \mathrm{~cm})$ which was significantly lower than all the other treatments. Use of only organic 
sources (100\% RDN) of nutrients viz. FYM, Pig manure, Vermicompost or Biofertilizers recorded non significant values among themselves however they were significantly inferior to those obtained with integrated use of 50\% RDNPK through inorganic sources and 50\% RDN through organic sources with or without biofertilizers during both the years. These findings indicated that gladiolus crop required high amount of nutrients for its proper growth and $100 \%$ replacement of nutrients through organic sources was unable to supply plant nutrients adequately keeping space with the requirement during its growth period. It might be attributed to slow mineralization rate of organic matter at initial growth stages and high $\mathrm{N}$ requirement during the period of formation of new corm. This is in confirmation with the findings of Kumar et al., (2013) in their experiment on potato. On the other hand, the rise in the height of plant in the integrated nutrient management might be because of the readily available form of nutrients. Plant height may be attributed to the presence and synthesis of gibberellins in organic manures. Gibberellins cause both cell elongation and division that stimulated elongation and resulted in increased plant height. These findings were in conformity with the findings of Shankar et al., (2010) and Prakash et al., (2015) in gladiolus. Moreover, application of biofertilizers in addition to organic manures and inorganic fertilizers might have increased the absorption of the macro and micro nutrients of plant. This might be due to fact that combined application of biofertilizers enhance the rate of mineralization of plant nutrients in soil and thus help in better nutrition of the crop that reflected in increasing plant height (Mondal et al., 2005; Sarkar et al., 2007; Ahmad et al., (2013).

The variation in leaves plant ${ }^{-1}$ was significantly influenced by different sources of nutrients. Data when analyzed revealed that $\mathrm{T}_{11}(50 \% \mathrm{NPK}+25 \% \mathrm{FYM}+$ Biofertilizers $)$ produced maximum leaves plant $^{-1}$ (9.63) followed by $\mathrm{T}_{12}(50 \% \mathrm{NPK}+25 \%$ Pig manure + Biofertilizers) (9.52), $\mathrm{T}_{7}(50 \% \mathrm{NPK}+50 \%$ Pig manure) (9.44) and $\mathrm{T}_{6}(50 \% \mathrm{NPK}+50 \%$ FYM) (9.42) which also showed statistically non significant response when compared among themselves. The treatment showing statistically most inferior response (8.12) could be adjudged as $\mathrm{T}_{0}$. The plots treated solely with organic nutrient source $\left(T_{1}, T_{2}\right.$ and $\mathrm{T}_{3}$ ) recorded lower values than the plots receiving combined nutrient sources $\left(\mathrm{T}_{6}, \mathrm{~T}_{7}\right.$, $\mathrm{T}_{8}, \mathrm{~T}_{11}, \mathrm{~T}_{12}$, and $\mathrm{T}_{13}$ ) showing that although organic manures are the source of all nutrients, crop response is more evident in the presence of chemical fertilizers with or without biofertilizers.

The magnitude of increase with respect to leaves per plant of $\mathrm{T}_{6}$ over $\mathrm{T}_{1}$ is $8.53 \%$ and that with $\mathrm{T}_{11}$ over $\mathrm{T}_{1}$ is $10.94 \%$ depicting that combined application of manure with inorganic fertilizer is better than its sole application while the combination of manure with inorganic fertilizer and biofertilizers in optimum dose is more effective than manure with inorganic fertilizer alone in influencing the number of leaves. These results need to be looked in the light of an increased nutrient availability especially nitrogen, as it is a constituent of protein, component of protoplasm and also increased chlorophyll content in leaves. All the factors contributed to cell multiplication, cell elongation and differentiation, which have resulted in better photosynthesis and ultimately respective growth. Dubey et al., (2008) and Singh (2005) reported that the profound effect of nitrogen fertilization on anatomical structure of gladiolus resulted production of more number of leaves.

The leaf area of the plant also plays an important role in photosynthetic activity as it intercepts more of radiant energy from sunlight. Different sources of fertilizers also largely influenced the leaf area as the 
variations differed significantly. On the basis of two year mean data on leaf area, maximum value $\left(130.56 \mathrm{~cm}^{2}\right)$ was recorded in $\mathrm{T}_{12}(50 \%$ NPK $+25 \%$ Pig manure + Biofertilizers). However, differences between the treatment effects of $\mathrm{T}_{12}, \mathrm{~T}_{11}(50 \% \mathrm{NPK}+25 \% \mathrm{FYM}+$ Biofertilizers) $\left(129.35 \mathrm{~cm}^{2}\right), \mathrm{T}_{7}(50 \% \mathrm{NPK}+$ $50 \%$ Pig manure) $\left(126.20 \mathrm{~cm}^{2}\right), \mathrm{T}_{13}(50 \%$ $\mathrm{NPK}+25 \%$ Vermicompost + Biofertilizers) $\left(122.05 \mathrm{~cm}^{2}\right)$ and $\mathrm{T}_{6}(50 \% \mathrm{NPK}+50 \% \mathrm{FYM})$ $\left(121.81 \mathrm{~cm}^{2}\right)$ were found at par. Among the organic treatments, $\mathrm{T}_{1}$ (FYM $40 \mathrm{t} \mathrm{ha}^{-1}$ ) recorded the maximum leaf area $\left(109.74 \mathrm{~cm}^{2}\right)$ however it was at par with $\mathrm{T}_{2}$ (Pig manure $35 \mathrm{t}$ $\left.\mathrm{ha}^{-1}\right)\left(105.62 \mathrm{~cm}^{2}\right)$ and $\mathrm{T}_{3}$ (Vermicompost $10 \mathrm{t}$ $\left.\mathrm{ha}^{-1}\right)\left(103.81 \mathrm{~cm}^{2}\right)$ which were significantly higher than control and biofertilizer treatments alone. On the other hand, the treatments consisting of $50 \%$ inorganic fertilizers and $50 \%$ organic manures recorded at par values among themselves as well as those treatments which consisted of $50 \%$ inorganic fertilizers with $25 \%$ organic manures and biofertilizers but significantly higher than those treatments containing $100 \%$ fertilizers through individual nutrient sources. Significantly lower leaf area $\left(89.96 \mathrm{~cm}^{2}\right)$ was obtained in control. Increase in vegetative growth might be due to better flow of macro and micro nutrients along with plant growth substances into the plant system in the plots applied with manures, biofertilizers and half of the recommended dose of fertilizer.

In addition to improving the soil physical properties, the growth promoting substances present in organic matter might have resulted in increased cell division and elongation leading to enhanced leaf expansion, thus leading to increase in the leaf area. The observed results are in agreement with the findings of Reshma et al., (2013) in flower crops. Kumar et al., (2011) reported that combined application of chemical fertilizers, biofertilizers and biostimulants showed a significant influence on growth of gladiolus cv. Sancerre.

\section{Flowering attributes}

The commercial value of a flower crop depends mainly on its specific quality attributes. In the present investigation, the flower attributes were significantly influenced by the use of various nutrient sources as depicted in Table 4. The analysis of data indicated that the minimum days to spike emergence (68.72) was recorded in $\mathrm{T}_{12}(50 \%$ $\mathrm{NPK}+25 \%$ Pig manure + Biofertilizers) which was at par with $\mathrm{T}_{11}(50 \% \mathrm{RDF}+25 \%$ FYM + Biofertilizers) (68.88), $\mathrm{T}_{13}$ (50\% NPK $+25 \%$ Vermicompost + Biofertilizers $)$ (71.10), $\mathrm{T}_{10}(75 \% \mathrm{NPK}+$ Biofertilizers $)$ (72.00) and $\mathrm{T}_{6}(50 \% \mathrm{NPK}+50 \% \mathrm{FYM})$ (72.69). The least responsive treatment was recorded with control (78.43). The earliness in spike emergence in INM might be ascribed to easy uptake of nutrients and simultaneous transport of growth promoting substances like cytokinin. An adequate supply of phosphorus in the early stages of growth is important for laying down the primordial for reproductive parts of the plant and helps in early maturity of crops. Ultimately, this has resulted in a better sink for quick mobilization of photosynthates and early transformation of plant parts from vegetative to reproductive phase. The result of present investigation is in close conformity with the findings of Parolekar et al., (2012) in tuberose; Pathak and Kumar (2009) in gladiolus.

The days needed for full opening of $1^{\text {st }}$ floret was significantly influenced by different sources of nutrients. $\mathrm{T}_{12}(50 \% \mathrm{NPK}+25 \% \mathrm{Pig}$ manure + Biofertilizers) recorded the least days (78.36) to full opening of $1^{\text {st }}$ floret which showed at par values with $\mathrm{T}_{11}(50 \% \mathrm{NPK}+$ $25 \%$ FYM + Biofertilizers) (78.41) and $\mathrm{T}_{13}$ $(50 \% \mathrm{NPK}+25 \%$ Vermicompost + Biofertilizers) (79.46), $\mathrm{T}_{10} \quad(75 \%$ NPK + Biofertilizers) (81.29) and $\mathrm{T}_{9}(50 \% \mathrm{NPK}+$ Biofertilizers) (82.44). On the contrary, the maximum days (90.00) to full opening of the 
$1^{\text {st }}$ floret was observed in control followed by $\mathrm{T}_{5}$ (Biofertilizers) with 87.06 days. Among different treatments, application of $50 \%$ recommended dose of fertilizers in combination with $25 \%$ of either FYM or Pig manure + Biofertilizers (either $\mathrm{T}_{11}$ or $\mathrm{T}_{12}$ respectively) recorded significantly less days to spike emergence and full opening of the first floret. This might be due to application of organic manures which led to improved soil texture by making soil loose thereby increasing the water holding capacity which encouraged early growth and development of corms and indirectly helped in early emergence of spike.

The readily available nutrients from 50\% RDF might have helped in building up of nutrition in corms, which might have improved the early vegetative growth of the plant which in turn had indirectly helped in early emergence of spike. Another probable reason for early heading and flowering in the plots which have received integrated nutrient treatments containing organic manures, inorganic fertilizers and biofertilizers might be that the hormones which enhanced early heading and flowering was secreted by Azospirillum and phosphotica. This result is in agreement with the findings of Srivastava et al., 2014 in tuberose and Dubey et al., 2008 in gladiolus who reported that application of biofertilizers would have helped in uptake of micronutrients and have provided essential plant growth promoting substances which resulted in early flowering.

INM might have role in supply of macro and micronutrients, enzymes and growth hormones and provide micronutrients such as $\mathrm{Zn}, \mathrm{Fe}, \mathrm{Cu}, \mathrm{Mn}$, etc. in an optimum level which helped in proper flower development. Further, increase in absorptive surface area of the roots due to the combined use of different nutrient sources might have led to enhanced uptake and translocation of available water and nutrients like $\mathrm{P}, \mathrm{Zn}, \mathrm{Fe}, \mathrm{Mg}$ and $\mathrm{Cl}$, ultimately resulting in better sink for faster mobilization of photosynthesis and early transformation of plant parts from vegetative to reproductive phase. Similar results were reported by Tripathi et al., (2013) in tuberose and Narendra et al., (2013) in gladiolus.

In gladiolus, the number of florets is an important criterion for the suitability of the cultivar for cut flower and bedding purposes. The data relating to florets spike ${ }^{-1}$, embodied in Table 4, revealed that the integrated application of nutrients produced maximum florets spike $^{-1}$ and was significantly higher than the sole application of the nutrient sources. $\mathrm{T}_{12}(50 \% \mathrm{NPK}+25 \%$ Pig manure + Biofertilizers) gave the highest number of florets (15.58) which was statistically at par with $\mathrm{T}_{11} \quad(50 \% \quad \mathrm{RDF}+25 \% \quad \mathrm{FYM}+$ Biofertilizers) (15.21), $\mathrm{T}_{7}(50 \% \mathrm{NPK}+50 \%$ Pig manure) (15.13), $\mathrm{T}_{6}(50 \% \mathrm{NPK}+50 \%$ FYM) (15.01) $\mathrm{T}_{13} \quad(50 \% \mathrm{NPK}+25 \%$ Vermicompost + Biofertilizers) (14.84), $\mathrm{T}_{4}$ $(100 \% \mathrm{NPK})$ and $\mathrm{T}_{8}(50 \% \mathrm{NPK}+50 \%$ Vermicompost) (14.53), while minimum number of florets (12.07) was obtained in control which was inferior to all the other treatments under study.

Maximum florets spike ${ }^{-1}$ obtained by the application of integrated treatments might be due to fast release of nutrients and increased levels of both macro and micronutrients and more absorption area. Increased plant growth and leaf area with these treatments might have resulted in the production of more photosynthates which might have consequently led to the production of more florets spike ${ }^{-1}$. These results were also found to be in conformity with the findings of Suseela et al., (2016).

Different INM oriented treatments produced significant response on length of spikes to varying proportions (Table 4). 


\begin{tabular}{|c|c|}
\hline \multicolumn{2}{|r|}{ Table.1 Treatment details } \\
\hline Notation & Treatments \\
\hline $\mathbf{T}_{0}$ & Control \\
\hline$T_{1}$ & FYM $\left(40 \mathrm{t} \mathrm{ha}^{-1}\right)$ \\
\hline $\mathbf{T}_{2}$ & Pig manure $\left(35 \mathrm{tha}^{-1}\right)$ \\
\hline $\mathbf{T}_{3}$ & Vermicompost $\left(10 \mathrm{t} \mathrm{ha}^{-1}\right)$ \\
\hline $\mathbf{T}_{4}$ & NPK 100\% RDF (200:200:200 kg NPK ha-1) \\
\hline $\mathbf{T}_{5}$ & Biofertilizers (Azospirillum + Phosphotica) \\
\hline$T_{6}$ & $50 \%$ NPK + 50\% FYM \\
\hline $\mathbf{T}_{7}$ & $50 \%$ NPK + 50\% Pig manure \\
\hline $\mathbf{T}_{8}$ & $50 \%$ NPK $+50 \%$ Vermicompost \\
\hline $\mathbf{T}_{9}$ & $50 \%$ NPK + Biofertilizers \\
\hline$T_{10}$ & 75\% NPK + Biofertilizers \\
\hline$T_{11}$ & $50 \%$ NPK + 25\% FYM + Biofertilizers \\
\hline$T_{12}$ & $50 \%$ NPK $+25 \%$ Pig manure + Biofertilizers \\
\hline $\mathbf{T}_{13}$ & $50 \%$ NPK + 25\% Vermicompost + Biofertilizers \\
\hline
\end{tabular}

\begin{tabular}{|l|c|c|c|}
\hline \multicolumn{4}{|c|}{ Table.2 Nutrient profiling of different organic manures } \\
\hline Organic manures & \multicolumn{2}{|c|}{ Nutrient concentration (\%) } \\
\cline { 2 - 4 } & $\mathrm{N}$ & $\mathrm{P}$ & $\mathrm{K}$ \\
\hline FYM & 0.5 & 0.4 & 0.5 \\
\hline Pig manure & 0.6 & 0.7 & 0.5 \\
\hline Vermicompost & 2.0 & 1.0 & 0.7 \\
\hline
\end{tabular}

Table.3 Response of organic and inorganic nutrient sources on the growth of Gladiolus primulinus cv. Candyman

\begin{tabular}{|l|l|l|l|l|}
\hline Treatments & $\begin{array}{l}\text { Days to } \\
\text { sprouting }\end{array}$ & Plant height $(\mathrm{cm})$ & $\begin{array}{l}\text { Leaves } \\
\text { plant }^{-1}\end{array}$ & Leaf area $\left(\mathrm{cm}^{2}\right)$ \\
\hline $\mathbf{T}_{\mathbf{0}}$ & 7.73 & 80.88 & 8.12 & 89.96 \\
\hline $\mathbf{T}_{\mathbf{1}}$ & 7.95 & 95.93 & 8.68 & 109.74 \\
\hline $\mathbf{T}_{\mathbf{2}}$ & 8.12 & 97.25 & 8.71 & 105.62 \\
\hline $\mathbf{T}_{\mathbf{3}}$ & 7.98 & 91.54 & 8.57 & 103.81 \\
\hline $\mathbf{T}_{\mathbf{4}}$ & 7.93 & 99.51 & 8.81 & 114.52 \\
\hline $\mathbf{T}_{\mathbf{5}}$ & 7.81 & 90.17 & 8.48 & 99.02 \\
\hline $\mathbf{T}_{\mathbf{6}}$ & 8.04 & 103.67 & 9.42 & 121.81 \\
\hline $\mathbf{T}_{\mathbf{7}}$ & 8.05 & 107.80 & 9.44 & 126.20 \\
\hline $\mathbf{T}_{\mathbf{8}}$ & 7.94 & 98.15 & 8.88 & 119.45 \\
\hline $\mathbf{T}_{\mathbf{9}}$ & 7.99 & 90.82 & 8.72 & 100.08 \\
\hline $\mathbf{T}_{\mathbf{1 0}}$ & 7.70 & 98.85 & 8.92 & 114.55 \\
\hline $\mathbf{T}_{\mathbf{1 1}}$ & 7.75 & 108.55 & 9.63 & 129.35 \\
\hline $\mathbf{T}_{\mathbf{1 2}}$ & 7.93 & 107.62 & 9.52 & 130.56 \\
\hline $\mathbf{T}_{\mathbf{1 3}}$ & 7.90 & 99.71 & 9.04 & 122.05 \\
\hline $\mathbf{S E m} \mathbf{C}$ & 0.34 & 2.37 & 0.18 & 3.11 \\
\hline $\mathbf{C D}$ at 5\% & $\mathrm{NS}$ & 7.73 & 0.59 & 10.16 \\
\hline
\end{tabular}


Table.4 Response of organic and inorganic nutrient sources on the flowering of Gladiolus primulinus cv. Candyman

\begin{tabular}{|l|l|l|l|l|l|l|l|l|}
\hline Treatments & $\begin{array}{l}\text { Days to } \\
\text { spike } \\
\text { emergence }\end{array}$ & $\begin{array}{l}\text { Days to full } \\
\text { opening of } \mathbf{~}^{\text {st }}\end{array}$ & $\begin{array}{l}\text { Floret. } \\
\text { fpike }\end{array}$ & $\begin{array}{l}\text { Spike } \\
\text { length } \\
\text { (cm) }\end{array}$ & $\begin{array}{l}\text { Rachis } \\
\text { length } \\
\text { (cm) }\end{array}$ & $\begin{array}{l}\text { Diameter of } \\
\text { floret }(\mathbf{c m})\end{array}$ & $\begin{array}{l}\text { Durability } \\
\text { of spikes } \\
\text { (days) }\end{array}$ & $\begin{array}{l}\text { Spikes } \\
\text { Plant }^{-1}\end{array}$ \\
\hline $\mathbf{T}_{\mathbf{0}}$ & 78.43 & 90.00 & 12.07 & 62.00 & 31.94 & 8.99 & 14.93 & 1.15 \\
\hline $\mathbf{T}_{\mathbf{1}}$ & 75.92 & 87.00 & 13.69 & 74.76 & 39.82 & 9.49 & 17.04 & 1.32 \\
\hline $\mathbf{T}_{\mathbf{2}}$ & 75.88 & 86.08 & 13.92 & 73.89 & 40.68 & 9.55 & 17.26 & 1.37 \\
\hline $\mathbf{T}_{\mathbf{3}}$ & 76.06 & 86.98 & 13.19 & 72.30 & 38.65 & 9.41 & 16.98 & 1.30 \\
\hline $\mathbf{T}_{\mathbf{4}}$ & 74.92 & 86.23 & 14.53 & 79.47 & 43.00 & 9.93 & 18.35 & 1.40 \\
\hline $\mathbf{T}_{\mathbf{5}}$ & 75.84 & 87.06 & 12.73 & 71.59 & 38.15 & 9.15 & 16.48 & 1.27 \\
\hline $\mathbf{T}_{\mathbf{6}}$ & 72.69 & 83.69 & 15.01 & 84.25 & 46.54 & 10.18 & 18.89 & 1.43 \\
\hline $\mathbf{T}_{\mathbf{7}}$ & 73.09 & 83.70 & 15.13 & 86.84 & 47.16 & 10.21 & 19.27 & 1.46 \\
\hline $\mathbf{T}_{\mathbf{8}}$ & 73.81 & 83.98 & 14.53 & 79.28 & 44.14 & 9.97 & 18.07 & 1.40 \\
\hline $\mathbf{T}_{\mathbf{9}}$ & 73.34 & 82.44 & 13.57 & 73.74 & 38.82 & 9.62 & 16.84 & 1.28 \\
\hline $\mathbf{T}_{\mathbf{1 0}}$ & 72.00 & 81.29 & 15.21 & 87.00 & 48.23 & 10.32 & 19.28 & 1.47 \\
\hline $\mathbf{T}_{\mathbf{1 1}}$ & 68.88 & 78.41 & 15.58 & 88.76 & 48.84 & 10.33 & 19.42 & 1.48 \\
\hline $\mathbf{T}_{\mathbf{1 2}}$ & 68.72 & 78.36 & 14.84 & 80.94 & 44.33 & 10.06 & 18.25 & 1.42 \\
\hline $\mathbf{T}_{\mathbf{1 3}}$ & 70.73 & 79.46 & 0.35 & 2.25 & 1.50 & 0.21 & 0.48 & 0.03 \\
\hline $\mathbf{S E m} \pm$ & 1.22 & 1.62 & 1.14 & 7.36 & 4.88 & 0.69 & 1.57 & 0.11 \\
\hline $\mathbf{C D}$ at 5\% & 3.99 & 5.27 & & & & & 1.37 \\
\hline
\end{tabular}

Length of spike ranged from $62.00 \mathrm{~cm}$ to $88.76 \mathrm{~cm}$ among the various treatments. $\mathrm{T}_{12}$ $(50 \%$ NPK $+25 \%$ Pig manure + Biofertilizers) was significantly better in improving the length of spike $(88.76 \mathrm{~cm})$ than most of the other treatments however it was at par with $\mathrm{T}_{11}(50 \% \mathrm{RDF}+25 \%$ FYM + Biofertilizers) $(87.00 \mathrm{~cm}), \mathrm{T}_{7}(50 \% \mathrm{NPK}+$ $50 \%$ Pig manure) $(86.84 \mathrm{~cm}), \mathrm{T}_{6}(50 \% \mathrm{NPK}+$ $50 \%$ FYM $)(84.25 \mathrm{~cm}), \mathrm{T}_{13}(50 \% \mathrm{NPK}+25 \%$ Vermicompost + Biofertilizers $)(80.94 \mathrm{~cm})$ and $\mathrm{T}_{10}(75 \% \mathrm{NPK}+$ Biofertilizers $)(80.02$ $\mathrm{cm})$.

The least effective treatment was noted as control $(62.00 \quad \mathrm{~cm})$ which differed significantly from the rest of the treatments. Rachis lengths of as affected by various nutrient sources are depicted in Table 4. Data when analyzed depicted that $\mathrm{T}_{12}(50 \% \mathrm{NPK}+$ $25 \%$ Pig manure + Biofertilizers) recorded maximum rachis length with a value of 48.84 $\mathrm{cm}$ which was at par with $\mathrm{T}_{11}(50 \%$
NPK + 25\% FYM + Biofertilizers) (48.23 $\mathrm{cm}), \mathrm{T}_{7}(50 \% \mathrm{NPK}+50 \%$ Pig manure) (47.16 $\mathrm{cm})$ and $\mathrm{T}_{6}(50 \% \mathrm{NPK}+50 \% \mathrm{FYM})(46.54$ $\mathrm{cm})$. The most inferior treatment pertaining to rachis length $(31.94 \mathrm{~cm})$ was recorded in control which was statistically lower than all the other treatments. Combined application of organic and inorganic nutrient sources in combination with the biofertilizers in optimum proportion might have enhanced the availability of nutrients in the soil which increased the synthesis of amino acids and chlorophyll formation and in return carbohydrate formation which ultimately resulted in the better growth and length of spike and rachis. Results indicated that the dose of organic manures can be replaced up to $50 \%$ with the addition of biofertilizers which can either improve or maintain the performance of crops as compared to the sole treatment of organic manures. However, the sole treatment of biofertilizer in the absence of organic manures does not produce 
significant effect over the control. This might be due to the low availability of organic substrates for the activity of microbial population as well as competition from soil native microorganisms. The increased spike length in the INM oriented treatments was probably due to the better vegetative growth whose result was later manifested through the improved reproductive characters. These results were similar to the works of Tripathi et al., (2012) who found that spike length was increased with the application of vermicompost and trichocompost along with $1 / 4$ RDF fertilizers.

A good flower size, an indicator of efficient culmination of utmost exploitation of available resources to their optimum, was significantly influenced by the various treatments under study. The diameter of floret, being one of the most important characters of gladiolus is greatly influenced by nutrient uptake, better mobilization and solubilisation of phosphate. The data analysis (Table 4$)$ revealed that $\mathrm{T}_{12}(50 \% \mathrm{NPK}+25 \%$ Pig manure + Biofertilizers) recorded higher diameter of floret $(10.33 \mathrm{~cm})$ and was at par with $\mathrm{T}_{11}(50 \% \mathrm{NPK}+25 \%$ FYM + Biofertilizers) $(10.32 \mathrm{~cm})$. On the contrary, the lowest floret diameter was registered in control and $\mathrm{T}_{5}$ (Biofertilizers), $8.99 \mathrm{~cm}$ and $9.15 \mathrm{~cm}$ respectively. The increase in floral characters due to integrated application of organic and inorganic fertilizers might be due to improved vegetative growth and healthy green leaves which in turn was manifested in higher assimilate synthesis thus leaded to production of more food material, which in turn might have been utilized for their translocation to the floral parts for better development of size and weight of flowers. Similarly, Dubey et al., (2010) reported that significant improvement in flower quality of gladiolus were recorded with the inoculation of Azotobacter + PSB, which might be due to increased availability of nitrogen and better mobilization, solubilization of phosphate and better uptake of micronutrients like $\mathrm{Zn}$, which is a precursor of auxin ultimately improved plant growth and flower spike. On the other hand, the reason behind the lowest mean diameter of florets in the spikes of control plots and the plots receiving individual nutrient sources may be due to uptake of essential nutrients in less than required amount leading to flaccidity and deplasmolysis of cells in turn leading to reduced size of cells and that of petals. Moreover, in the spikes from INM treated plots, there may be adequate availability of carbohydrates which might have facilitated higher rate of respiration necessary for cell division, cell expansion and providing carbon skeleton for the tissue structure contributing to floret expansion, formation of cell constituents and thus caused increased floret size (Singh et al., 2005).

The observations pertaining to flowering duration (Table 4) inferred that duration of flowering recorded from full bloom of first floret up to the stage till $70 \%$ florets wilt, was found more in $\mathrm{T}_{12}(50 \% \mathrm{NPK}+25 \% \mathrm{Pig}$ manure + Biofertilizers) (19.42 days) which was at par with $\mathrm{T}_{11}(50 \% \mathrm{NPK}+25 \% \mathrm{FYM}+$ Biofertilizers) (19.28 days), $\mathrm{T}_{7}(50 \% \mathrm{NPK}+$ $50 \%$ Pig manure) (18.84 days) and $\mathrm{T}_{10}(75 \%$ NPK + Biofertilizers) (18.37 days). The shortest durability of spikes was observed in control. Duration of flowering was reduced by almost a week in control grown plants (14.93 days). The longer durability of spikes in INM might be due to optimum content of nutrients in the plant tissues and their continuous supply to the flowering spikes which might have improved the quality of the spikes and more florets and longer durability of individual florets which in turn might have increased the self life of the spikes. Singh et al., (2008) and Dubey and Misra (2006) also found best growth and flowering characters in gladiolus with the combined application of nutrients. 
Spike plant ${ }^{-1}$ was significantly influenced by the different treatments under study (Table 4). $\mathrm{T}_{12}(50 \%$ NPK $+25 \%$ Pig manure + Biofertilizers) gave the highest spike plant $^{-1}$ (1.48) which was at par with $\mathrm{T}_{11}(50 \% \mathrm{NPK}+$ $25 \%$ FYM + Biofertilizers) (1.47) and $\mathrm{T}_{7}$ (50\% NPK $+50 \%$ Pig manure) (1.46). Control recorded minimum spike plant $^{-1}$ (1.15) which differed from other treatments significantly. The increased spikes plant $^{-1}$ might be due to continuous supply and uptake of nutrients with higher moisture content, conversion of non available nutrients to available forms by biofertilizers during different growth stages which stimulate more cell elongation and cell division lead to more number of leaves. Leaves are the main photosynthetic apparatus in plants, synthesizing various metabolites required for plant growth and development. Nitrogen being a constituent of chlorophyll might have increased the leaf area there by more synthesis of carbohydrates, which are utilized in building up of new cells then finally leads to more spike production. These results are in agreement with that of Pansuriya (2015) in gladiolus. A thorough analysis of the data proved that a difference of $25 \%$ or $50 \%$ manures or compost in the INM treatments produced yield equivalent to that produced by half dose of NPK. The results are in accordance with the findings of Singh et al., (2008) who reported that the reduction to the tune of $25 \%$ in recommended dose of $\mathrm{N}, \mathrm{P}$ and $\mathrm{K}$ could be made with the application of farmyard manure.

From the present study, it may be concluded that integrated application of $50 \%$ NPK (100:100:100 kg ha ${ }^{-1}$ ) and 25\% Pig manure (8.75 $\mathrm{t} \mathrm{ha}^{-1}$ ) along with Azospirillum and Phosphotica is considered the most beneficial treatment in terms of plant growth and flowering attributes of Gladiolus primulinus cv. Candyman under the foothill condition of Nagaland. Further, application of $50 \%$ NPK
(100:100:100 kg ha ${ }^{-1}$ ) and 25\% FYM (10 t $\mathrm{ha}^{-1}$ ) along with Azospirillum and Phosphotica may also be done with equivalent yield potential. Thus, optimum mineral nutrients in conjunction with organic manures and biofertilizers can play a vital role in exploiting high yield potential with good quality spikes of gladiolus through its favourable effect on nutrient supply.

\section{References}

Ahmad, A., Mehmood, T., Hussain, R., Bashir, A., Raza, S., Najam-ud-Din and Ahmad, A. 2013. Investigation of biofertilizers influence on vegetative growth, flower quality, bulb yield and nutrient uptake in gladiolus (gladiolus grandiflorus l.). International Journal of Plant, Animal and Environmental Sciences. 4 (1): 94-99.

Dubey, R. K. and Misra, R. L., 2006, Study of chemical and bio-fertilizers on gladiolus. Progressive Horticulture. 38 (2): 165-171.

Dubey, R. K., Kumar, P., Singh, N. and Kumar, R. 2008. Effect of Trichoderma viride and Pseudomonas fluorescens on growth and flowering of gladiolus. Indian Journal of Ecology. 35 (1): 554556.

Dubey, R. K., Misra, R. L., Singh, S. K. and Manisha. 2010. Efficacy of bio- and chemical fertilizers on certain floral qualities of gladiolus. Indian Journal of Horticulture. 67 (Special Issue): 382385.

Gagbhiye, B. R., Vetal, R. A., Puri, A. N. and Adsul, P. B. 2013. Response of FYM, $\mathrm{N}, \mathrm{P}$ and $\mathrm{K}$ levels on growth and flowering of gladiolus (Gladiolus grandiflorus) cv. White Prosperity. The Journal of Rural and Agricultural Research. 13 (2): 94-97.

Kumar, M., Baishya, L. K., Ghosh, D. C., Ghosh, M., Gupta, V. K. and Verma, M. 
R. 2013. Effects of organic manures, chemical fertilizers and biofertilizers on growth and productivity of rainfed potato in the Eastern Himalayas. Journal of Plant Nutrition. 36: 10651082.

Mondal, S. S., Acharya, D., Ghosh, A. and Bug, A. 2005. Integrated nutrient management on the growth, productivity and quality of potato in indo-gangetic plain of west Bengal. Potato Journal. 32: 75-78.

Mondal, S. S., Acharya, D., Ghosh, A. and Bug, A. 2005. Integrated nutrient management on the growth, productivity and quality of potato in Indo-Gangetic plain of west Bengal. Potato Journal. 32: 75-78.

Narendra, C., Swaroop, K., Janakiram, T., Biswas, D. R. and Singh, G. 2013. Effect of integrated nutrient management on vegetative growth and flowering characters of gladiolus. Indian Journal of Horticulture. 70 (1): 156-159.

Panse, V. G. and P. V. Sukhatme. 1989. Statistical Methods for Agricultural Workers. ICAR, New Delhi.

Pansuriya, P. B. and Chauhan, R.V. 2015. Effect of integrated nutrient management on growth, yield and quality of gladiolus (Gladiolus grandiflorus L.) cv. Psittacinus Hybrid. Journal of Horticulture. 2: 128.

Parolekar, S. S., Chawla, S. L., Ahlawat, R. D., Baghele, and Gurjar, R. A. 2012. Response of bio-fertilizers and their combination with different of chemical fertilizers on Tuberose (Polianthes tuberose L.) cv. Prajwal. Journal of Ornamental Horticulture. 15 (3 \& 4): 227-232.

Pathak, G. and Kumar, P. 2009. Influence of organics on floral attributes and shelf life of gladiolus (Gladiolus hybrida) cv. White Prosperity. Progressive
Horticulture. 41(1): 116-119.

Prakash, S., Kushwahsa, I. K., Singh, M. and Shahi, B. P. 2015. Effect of vermicompost and bio-control agents on growth and flowering of gladiolus $\mathrm{cv}$. Pusakiran. Annals of Horticulture. 8 (1): 110-112.

Reshma, M., Sushma, K. and Aruna, J. 2013. Effect of integrated supply of different fertilizers and organic manure on yield of tuberose. Journal of Biological Agriculture. 3 (14): 100-101.

Sarkar, B., Mondal, S. S., Nayak, S. S., Saha, M. and Biswas, S. 2007. Integrated nutrient management for the productivity and quality improvement of potato under irrigated condition. Potato Journal. 34: 99-100.

Shankar, L., Lakhawat, S. S. and Choudhary, M. K. 2010. Effect of organic manures and bio-fertilizers on growth, flowering and bulb production in tuberose. Indian Journal of Horticulture. 64: 554-556.

Sharma, J. R., Gupta, R. B. and Kaushik, R. A. 2003. Growth and flowering of gladiolus as affected by $\mathrm{N}$ and $\mathrm{P}$ levels. Journal of Ornamental Horticulture. 6 (1): 76-77.

Singh, A. K. 2005. Response of rose plant growth and flowering to organic and inorganic fertlization. Journal of Ornamental Horticulture. 8 (4): 296298.

Singh, A., Kumar, J., Kumar, P. and Singh, V. P. 2005. Influence of 8-Hydroxy Quinoline (8-HQ) and sucrose pulsing on membrane stability and postharvest quality of gladiolus cut spikes. Journal of Ornamental Horticulture. 8 (4): 243248.

Singh, D. P., Prakash, S. and Singh, A. P. 2008. Response of vermicompost and bio-fertilizer on growth and flowering in gladiolus cv. Red Beauty. In: Proceedings of National Symposium on Recent Advances in Indian Floriculture, 
69.

Srivastava, R., Preetham, S. P. and Satish Chand. 2014. Effect of organic manures and biofertilizers on vegetative, floral and post harvest attributes in tuberose (Polianthes tuberosa) var. Shringar. Asian Journal of Biological and Life Sciences. 3 (1): 6-9.

Suseela, T., Chandrasekha, R., Bhaskar, V. V., Suneetha, D. R. S. and Umakrishna, K. 2016. Effect of organic manures, inorganic fertilizers and micronutrients on vegetative and floral characters of tuberose (Polianthes tuberosa L.) cv. 'Suvasini'. International Journal of
Scientific and Research Publications. 6 (2): 170-173.

Tripathi, S. K., Malik, S., Kumar, A. and Kumar, V. 2013. Effect of integrated nutrient management on bulb yield of tuberose (Polianthes tuberosa L.). cv. Suvasini. Asian Journal of Horticulture. 3 (1): 150-154.

Tripathi, S. K., Malik, S., Singh, P., Dhyani, B. P., Kumar, V., Dhaka, S. S. and Singh, J. P. 2012. Effect of integrated nutrient management on cut flower production of tuberose (Polianthes tuberosa L.) cv. Suvasini. Annals of Horticulture. 6 (1): 149-152.

\section{How to cite this article:}

Nini R. Kuotsu, Rokolhuii Keditsu and Laishram Hemanta 2018. Response of Organic and Inorganic Nutrient Sources on the Growth and Flowering of Gladiolus primulinus cv. Candyman. Int.J.Curr.Microbiol.App.Sci. 7(05): 2537-2547.

doi: https://doi.org/10.20546/ijcmas.2018.705.292 